\title{
GLOSY
}

\author{
MICHAŁ P. ZIEMIAK \\ https://doi.org/10.33995/wu2019.3.6
}

\section{Glosa do uchwały Sądu Najwyższego z dnia 10 sierpnia 2018 roku (III CZP 13/18)}

Glosowana uchwała dotyczy wywołujqcych wciq̨ż kontrowersje umów ubezpieczenia na życie z ubezpieczeniowym funduszem kapitałowym (UFK). Na przestrzeni lat ogniskowały one szereg problemów, poczqwszy od zjawiska missellingu, a skończywszy na abuzywnym charakterze szeregu ich postanowień. Sad Najwyższy przyjał, że w takiej właśnie umowie roszczenie o wypłatę wartości wykupu ubezpieczenia niestanowiqcej kosztów udzielonej ochrony ubezpieczonej przedawnia się w terminie określonym w art. 118 k.c. Zdaniem Autora stanowisko takie wywołuje szereg watpliwości, a do przedawnienia roszczeń we wskazanym zakresie winien znaleźć zastosowanie art. 819 § 1 k.c.

Słowa kluczowe: UFK, przedawnienie roszczeń, wartość wykupu. umowa ubezpieczenia.

Teza: W umowie ubezpieczenia na życie z ubezpieczeniowym funduszem kapitałowym roszczenie o wypłatę wartości wykupu ubezpieczenia niestanowiącej kosztów udzielonej ochrony ubezpieczonej przedawnia się w terminie określonym w art. 118 k.c.

\section{Wstęp}

Glosowana uchwała dotyczy wywołujących wciąż kontrowersje umów ubezpieczenia na życie z ubezpieczeniowym funduszem kapitałowym (UFK). Na przestrzeni lat ogniskowały one szereg problemów, poczạwszy od zjawiska missellingu, a skończywszy na abuzywnym charakterze szeregu ich postanowień. W tym zakresie szczególnie istotne dla klientów ubezpieczycieli były klauzule statuujące tzw. opłaty likwidacyjne, które umożliwiały zatrzymanie przez zakład ubezpieczeń części wypłacanych ubezpieczającemu (lub ubezpieczonemu) środków, a więc zazwyczaj określona procentowo część tzw. wypłaty wartości wykupu. Gwoli ścisłości należy za Magdalena Szczepańską wskazać, że wykup może w ubezpieczeniu z UFK przyjąć dwie postacie: wykupu całkowitego i częściowego. Pierwsza postać oznacza formę wypłaty całości środków zgromadzonych na rachunku ubezpieczającego i we wszystkich funduszach, w których ulokował on środki. Z wypłata 
tą wiąże się wygaśnięcie stosunku ubezpieczenia ${ }^{1}$. Wykup częściowy nie skutkuje ustaniem stosunku ubezpieczenia i polega na cząstkowej wypłacie (często periodycznej) środków z funduszy?

$\mathrm{Na}$ tle wspomnianych opłat likwidacyjnych toczyło się przed sądami powszechnymi wiele sporów, które koncentrowały się chociażby na ich wysokości ${ }^{3}$. I choć analizowane orzeczenie dotyczy przedawnienia roszczeń o samą wypłatę wartości wykupu, to jego kontekst wydaje się być o wiele szerszy - SN de facto przesądził o charakterze umowy ubezpieczenia z UFK jako umowy mieszanej. Tym bardziej więc uchwała zapadła w sprawie III CZP 13/18 zasługuje na szczególną uwagę.

\section{Motywy rozstrzygnięcia}

Glosowana uchwała zapadła na skutek pytania prawnego wystosowanego przez sad okręgowy, rozpatrujacy apelację powódki w sprawie przeciwko zakładowi ubezpieczeń o zapłatę bezpodstawnie pobranej - zdaniem powódki - opłaty manipulacyjnej (likwidacyjnej). Opłata miała zostać pobrana w związku z rozwiązaniem łączącej strony umowy ubezpieczenia na życie z UFK. Sąd I instancji oddalił powództwo ${ }^{4}$, uwzględniając podniesiony przez pozwanego zarzut przedawnienia roszczeń. Z ustaleń tego sądu wynikało, że strony w dniu 7 sierpnia 2007 roku zawarły umowę ubezpieczenia, która z kolei uległa rozwiązaniu w dniu 10 lutego 2010 roku wskutek nieopłacenia przez powódkę składki ${ }^{5}$. Pozwany, wypłacając wartość wykupu ubezpieczenia, zatrzymał wówczas środki pieniężne stanowiące opłatę likwidacyjną w dochodzonej kwocie. Sąd I instancji wyraził poglad, że przepis art. 819 § 1 k.c. ${ }^{6}$ ma zastosowanie do wszelkich roszczeń, jakie wynikaja z umowy ubezpieczenia, w tym roszczeń o nienależyte jej wykonanie i wykluczył dopuszczalność zastosowania w takiej sytuacji, jako podstawy prawnej realizowanego roszczenia, przepisów o bezpodstawnym wzbogaceniu. Są okręgowy powział poważne wątpliwości co do podstaw wskazanego rozstrzygnięcia. Wątpliwości te ujał w następujące zagadnienie prawne: „Czy do roszczenia o wypłatę części świadczenia wykupu zatrzymanego przez ubezpieczyciela na podstawie abuzywnych postanowień umowy ubezpieczenia na życie z funduszem kapitałowym, przysługujacego ubezpieczającemu lub ubezpieczonemu będącemu konsumentem przeciwko ubezpieczycielowi, ma zastosowanie trzyletni termin przedawnienia zgodnie z przepisem art. $819 \S 1$ k.c., czy termin dziesięcioletni zgodnie z przepisem art. 118 k.c.?".

Sąd Najwyższy wskazał, że zagadnienie charakteru prawnego umowy ubezpieczenia na życie z UFK wywołuje wạtpliwości i w orzecznictwie, i w doktrynie. Wynikają one z faktu, że umowa ta nie

1. M. Szczepańska, Wypłata wartości wykupu w umowie ubezpieczenia na życie z UFK, „Wiadomości Ubezpieczeniowe" 2015, nr 3, s. 102.

2. Ibidem, s. 102.

3. W pierwszych latach obowiązywania umowy ubezpieczenia z UFK opłaty takie mogły wynieść od 80 do nawet 100\% wartości wykupu.

4. Mimo oddalenia powództwa, sąd I instancji uznał jednak postanowienie OWU uprawniające ubezpieczyciela do ustalenia i pobrania z subkonta składek regularnych opłaty likwidacyjnej ( $§ 18$ ust. 6 OWU) za niedozwoloną klauzulę umowną, wskazując na jej sprzeczność z dobrymi obyczajami i na rażące naruszenie interesu konsumenta w rozumieniu art. $385^{3}$ pkt 12, 13, 14, 16 i 17 k.c. Wskazana ocena tego postanowienia została podtrzymana przez są II instancji.

5. Powództwo wytoczono po upływie 3 lat od daty rozwiązania umowy.

6. Ustawa z dnia 23 kwietnia 1964 r. - Kodeks cywilny Dz. U. z 2019 r. poz. 1145 ze zm. 
tylko służy udzieleniu ochrony ubezpieczeniowej, ale realizuje także cel inwestycyjno-oszczędnościowy i cel ten częstokroć jest dominujacy. Zdaniem SN w założeniu ustawodawcy taka umowa to umowa ubezpieczenia, w której strony uzgadniaja, iż część składek ubezpieczeniowych jest „alokowana” w jednostki ubezpieczeniowego funduszu kapitałowego, czyli tworzonego z tych składek wydzielonego funduszu aktywów, inwestowanego zgodnie z umową i zarzadzanego przez ubezpieczyciela (ewentualnie) na koszt i ryzyko ubezpieczającego. Koniecznym elementem takiej umowy - obok świadczeń ubezpieczeniowych zakładu ubezpieczeń - jest możliwość wykupu ubezpieczenia. Zawieranie przez zakłady ubezpieczeń umów ubezpieczenia z UFK, także tych, w których cel inwestycyjny (oszczędnościowy) ma charakter dominujący, wchodziło w zakres ich dozwolonej działalności ubezpieczeniowej (art. 3 ust. 1 i 2 u.d.u. '). I chociaż u.d.u. zaliczała umowy z UFK do ogólniejszej kategorii umów ubezpieczenia na życie (a ustawodawca posługuje się w odniesieniu do takich umów podstawową siatką pojęciową właściwą umowom ubezpieczenia), to jednak ustawa nie przesądza ich charakteru prawnego. Zdaniem SN celem przepisów u.d.u., a także innych ustaw, w których pojawia się definicja UFK ${ }^{8}$, nie było normowanie praw i obowiązków stron uwzględnionych w niej umów, lecz określenie warunków wykonywania działalności w zakresie ubezpieczeń osobowych i ubezpieczeń majątkowych (bądź innej działalności).

SN zauważył, że kwalifikacja prawna umowy ubezpieczenia z UFK jest w doktrynie sporna, przy czym wyrażane sạ poglaady, że chodzi o szczególny rodzaj (podtyp) umowy ubezpieczenia osobowego uregulowanej w art. 805 i następnych k.c., lub też że chodzi o umowę mieszaną (nienazwana], do której w zasadzie należy stosować przepisy k.c. dotyczące umowy ubezpieczenia na życie z zastrzeżeniem wyjątków uzasadnionych szczególną naturą umowy z UFK. Watpliwości te znalazły odzwierciedlenie także w nielicznych, jak dotychczas, orzeczeniach SN dotyczących tej kategorii umów. Zdaniem Sądu z orzeczeń tych płyną następujące wnioski:

- umowa ubezpieczenia z UFK może być uznana za „umowę mieszaną” z elementami klasycznego modelu umowy ubezpieczenia na życie i postanowieniami charakterystycznymi dla umów, których celem jest inwestowanie kapitału, szczególnie gdy wynikająca z umowy ochrona ubezpieczeniowa ma charakter symboliczny, a dominuje aspekt kapitałowy uzasadniajaccy pogląd, że cel umowy zakłada istnienie długotrwałego stabilnego stosunku prawnego łączącego strony w celu zgromadzenia jak najwyższego kapitału i wygenerowania możliwie najlepszego efektu ekonomicznego dla ubezpieczającego, co zapewnia korzyści także ubezpieczycielowi ${ }^{9}$;

- z perspektywy funkcjonalnej tego rodzaju umowa opiera się na połączeniu elementów umowy ubezpieczenia z elementami umowy inwestycyjnej, przy czym natężenie cech umowy ubezpieczenia lub umowy o inwestowanie umówionej sumy pieniężnej kształtuje się różnie, w zależności od woli stron. Umowy z UFK zostały więc „genetycznie” oparte na konstrukcji umowy ubezpieczenia i przewiduja - obok elementu zarządzania przez ubezpieczyciela kapitałem ubezpieczającego - także typowe elementy wskazane w art. 805 k.c. jako essentialia negotii tej umowy. Z konstrukcyjnego punktu widzenia umowy te stanowią umowę ubezpieczenia

7. Chodzi tu o nieobowiązującạ już ustawę z dnia 22 maja 2003 r. o działalności ubezpieczeniowej (tekst jedn. Dz. U. 2015, poz. 1206).

8. Zob. m.in. ustawę z dnia 20 kwietnia 2004 r. o pracowniczych programach emerytalnych (tekst jedn. Dz. U. 2016, poz. 1449)

9. Zob. wyrok SN z dnia 18 grudnia 2013 r., I CSK 149/13 (OSNC 2014, z. 10, poz. 103). 
„wzbogacona” o element inwestycyjny - polegający na zarzadzaniu przez ubezpieczyciela środkami wpłaconymi w ramach składek w celu wypracowania zysku dla ubezpieczajacego ${ }^{10}$;

- odnośnie do niedozwolonego charakteru klauzul dotyczących wypłaty wartości wykupu, stwierdzenie abuzywności postanowień umowy ubezpieczenia należy kwalifikować jako zdarzenie prawne rodzące obowiązek dokonania pomiędzy jej stronami odpowiednich rozliczeń, których podstawą są przepisy ustawy o nienależnym świadczeniu. W związku z tym SN wspomniał, że należności będące przedmiotem zwrotu nie będą miały cech „świadczenia wykupu z umowy ubezpieczenia", a odwoływanie się do tego pojęcia umownego może mieć tylko charakter pomocniczy, przydatny przy wyliczeniach, nie zaś definicyjny ${ }^{11}$.

Ostatecznie, do rozstrzygnięcia o zastosowaniu terminów przedawnienia z art. 118 k.c. do roszczenia o wypłatę wartości wykupu w umowie ubezpieczenia z UFK doprowadziły SN następujące konkluzje:

- o wyborze przepisów prawa krajowego właściwych dla oceny skutków prawnych umów z UFK nie może jednak wyłacznie decydować stosowana w tych umowach „ubezpieczeniowa” siatka pojęciowa, rozstrzygające znaczenie należy bowiem przypisać analizie sensu i celu umowy. W wielu wypadkach umowa taka jedynie w ograniczonym zakresie realizuje podstawowy cel kodeksowej umowy ubezpieczenia, jakim jest przejęcie przez ubezpieczyciela ciążącego na ubezpieczonym (ewentualnie uposażonym) ryzyka związanego z zajściem określonego wypadku w życiu ubezpieczonego (jest to szczególnie wyraziste w sytuacji, w której suma ubezpieczenia wypłacanego na wypadek śmierci lub dożycia określonego wieku odpowiada w zasadzie wartości zgromadzonych jednostek funduszu);

- w analizowanych umowach nie chodzi - jak w przypadku tradycyjnego wykupu ubezpieczenia osobowego - o zwrot części składki nadpłaconej w początkowym okresie w związku z nierównomiernym rozłożeniem ryzyka ochrony ubezpieczeniowej (wzrastającym z biegiem czasu), lecz o wypłatę zgromadzonych i inwestowanych oszczędności. W ramach zobowiązań ubezpieczyciela na plan pierwszy wysuwa się wówczas odpłatny obowiązek zarządzania funduszem kapitałowym pochodzącym ze składek ubezpieczającego oraz obowiązek zapłaty wartości wykupu, będaccy obligatoryjnym elementem umowy z UFK (por. art. 13 ust. 4 pkt 2 u.d.u.);

- umowa ubezpieczenia z UFK, zawierająca w mniejszym czy większym stopniu element ubezpieczeniowy, ma charakter mieszany w tym sensie, iż przy wykorzystaniu konstrukcji umowy ubezpieczenia może realizować - także w dominującym stopniu - cel inwestycyjny. Zgodnie z wolą ustawodawcy nawet ów dominujący cel inwestycyjny nie prowadzi do absorpcji umów z UFK do reżimu prawnego umów inwestycyjnych. Przeciwnie, z omawianych przepisów wyłania się wola traktowania takich umów jako umów ubezpieczenia osobowego, co jednak nie powinno być odczytywane jako decyzja co do ich pełnej absorbcji w kodeksowe ramy takich ubezpieczeń. Wprawdzie do umów takich należy w zasadzie stosować przepisy kodeksu cywilnego o umowie ubezpieczenia (ubezpieczenia osobowego, ubezpieczenia na życie), jednakże - ze względu na ich cel inwestycyjny (zwłaszcza dominujący) - z wyłączeniem albo

10. Zob. wyrok SN z dnia 22 listopada 2017 r., IV CSK 61/17 (niepubl.), w którym ostatecznie przyjęto, że w świetle postanowień umowy stanowiącej podstawę rozstrzygnięcia stosunek ubezpieczenia pozostaje wyłącznie „forma”, w której ramach miał być realizowany cel inwestycyjny - mający z reguły podstawowe znaczenie dla umowy ubezpieczenia z elementami umowy inwestycyjnej. W konsekwencji SN zgodził się z poglądem, że kwestionowana przez powoda umowa została zawarta w zgodzie z art. 805 k.c., ergo nie może być uznana za nieważną.

11. Zob. wyrok SN z dnia 28 marca 2018 r., V CSK 398/17 (niepubl.). 
ograniczeniem zastosowania tych unormowań, które nie przystają do tego inwestycyjnego charakteru (zdaniem SN chodzi tu m.in. 0 art. 813 czy 817 k.c., który uzależnia wypłatę świadczenia od zajścia wypadku ubezpieczeniowego];

- wypłata wartości wykupu nie jest z pewnością świadczeniem ubezpieczeniowym, o którym mowa w art. $805 \S 1$ k.c., gdyż obowiązek jej dokonania nie powstaje w razie zajścia określonego w umowie wypadku ubezpieczeniowego, lecz w razie ziszczenia się innych zdarzeń, a w szczególności wypowiedzenia umowy albo jej rozwiązania wskutek nieopłacenia składki. Odrębność ta znalazła wyraz i potwierdzenie w terminologii chociażby art. 23 ust. 1 pkt 2 ustawy z dnia 11 września 2015 roku o działalności ubezpieczeniowej i reasekuracyjnej ${ }^{12}$ rozróżniajacym „świadczenia z umowy ubezpieczenia” z tytułu śmierci ubezpieczonego i dożycia ubezpieczonego do końca okresu ochrony ubezpieczeniowej od „wartości całkowitego i częściowego wykupu ubezpieczenia”. Pozwala to stwierdzić - z uwzględnieniem mieszanego charakteru umowy z UFK - że w istocie nie chodzi tu o roszczenie z umowy ubezpieczenia w rozumieniu art. 819 § 1 k.c.;

- $\quad$ wreszcie - zdaniem SN - za stanowiskiem takim przemawiają także względy funkcjonalne. Zważywszy tożsamość celów inwestycyjnych umowy z UFK i innych instrumentów inwestycyjnych, przyjmowanie w odniesieniu do roszczeń o wypłatę wartości wykupu krótszych terminów przedawnienia niż w przypadku tych instrumentów - np. podlegającego przedawnieniu na zasadach ogólnych roszczenia o odkupienie jednostek uczestnictwa funduszu inwestycyjnego nie byłoby uzasadnione. Argumentów na rzecz tej tezy dostarcza także art. 731 k.c., wyłączajacy zastosowanie krótkiego, dwuletniego terminu przedawnienia roszczeń wynikajacych ze stosunku rachunku bankowego do roszczeń o zwrot wkładów oszczędnościowych. Wskazuje on bowiem na dążenie ustawodawcy do wzmożonej ochrony prawa do wypłaty oszczędzanych środków, a racja ta jest w pełni aktualna w przypadku roszczenia o wykup wartości ubezpieczenia UFK, realizującego cele oszczędnościowo-inwestycyjne.

Ostatecznie więc SN przyjął, że umowa ubezpieczenia z UFK ma de facto charakter mieszany, co determinuje stosowanie art. 118 k.c. odnośnie do terminu przedawnienia roszczenia o wypłatę wartości wykupu, które z kolei nie jest świadczeniem z umowy ubezpieczenia.

\section{Polemika z rozstrzygnięciem SN}

Mimo szerokich i dogłębnych analiz ujętych w uzasadnieniu, z glosowanym orzeczeniem, przynajmniej w pewnych aspektach można polemizować. Wynika to przede wszystkim z kategorycznego twierdzenia SN, że „dominujący cel inwestycyjny nie prowadzi do absorpcji umów z UFK do reżimu prawnego umów inwestycyjnych. Przeciwnie, z omawianych przepisów wyłania się wola traktowania takich umów jako umów ubezpieczenia osobowego, co jednak nie powinno być odczytywane jako decyzja co do ich pełnej absorbcji w kodeksowe ramy takich ubezpieczeń". Nie chodzi tu o samą kwalifikację umowy ubezpieczenia z UFK jako umowy mieszanej - co raczej nie budzi już kontrowersji czy wạtpliwości w doktrynie oraz orzecznictwie - lecz o zakres stosowania przepisów k.c. o umowie ubezpieczenia do tego typu kontraktów. Przede wszystkim należy zgodzić się z wyrażonym przez SN we wspomnianym wyroku z dnia 22 listopada 2017 roku (IV CSK 61/17) pogladem, że umowy

12. Tekst jedn. Dz. U. 2018, poz. 999 (dalej: u.dz.u.r.). 
z UFK sa „genetycznie” oparte na konstrukcji umowy ubezpieczenia na życie, ergo w każdym przypadku zawierają element ochronny. Potwierdza to już samo brzmienie grupy III działu I załącznika do u.dz.u.r., a także treść art. 21-24 oraz 26 tej ustawy. Inaczej mówiąc, umowy ubezpieczenia z UFK nie mają charakteru umów nienazwanych, a sama regulacja u.dz.u.r. nie służy wyłącznie „legitymizacji” możliwości oferowania takich umów przez zakłady ubezpieczeń. Przede wszystkim wskazane przepisy u.dz.u.r. w żaden sposób nie rozróżniaja „zwykłych” umów ubezpieczenia od umów z UFK, a jedynie traktują element inwestycyjny jako sui genreis część dodatkową umowy ubezpieczenia. Idac dalej, artykuły 21-24 oraz 26 u.dz.u.r. w drobiazgowy sposób nie tylko określaja wymogi formalne dotyczące umów z UFK, ale także statuują szereg praw i obowiązków jej stron, w tym:

- obowiązek ankietowania ubezpieczającego (ubezpieczonego) przed zawarciem umowy oraz obowiązek przedstawienia „rekomendacji” przez zakład ubezpieczeń (art. 21);

- przedkontraktowe obowiązki informacyjne zakładu ubezpieczeń (art. 22);

- obligatoryjne elementy umowy z UFK (art. 23);

- prawo do odstapienia lub wystapienia z umowy ubezpieczenia na życie z UFK (art. 26).

Powołane przepisy posługują się pojęciami „umowy ubezpieczenia”, „ubezpieczającego” czy „ubezpieczonego”, sam zaś np. art. 21 ust. 3 stanowi, że na podstawie analizy informacji uzyskanych od ubezpieczającego zakład ubezpieczeń przedstawia ubezpieczającemu propozycje ubezpieczenia (a nie propozycje zawarcia innych umów), odpowiednie do potrzeb ubezpieczającego wraz z uzasadnieniem, które obejmuje w szczególności zidentyfikowanie potrzeb ubezpieczającego oraz wyjaśnienie, w jaki sposób przedstawione propozycje zaspokajają te potrzeby. Co więcej, gdyby zamierzeniem ustawodawcy było umożliwienie ubezpieczycielom oferowania możliwości zawarcia umów nienazwanych o charakterze inwestycyjno-oszczędnościowym, to z pewnością znalazłoby to odzwierciedlenie w treści art. 4 ust. 11 u.dz.u.r. Trzeba pamiętać, że zgodnie z art. 4 ust. 3 u.dz.u.r. zakład ubezpieczeń nie może wykonywać działalności innej niż ubezpieczeniowa i bezpośrednio z nią związana, z zastrzeżeniem ust. 6 (reasekuracja) i właśnie ust. 11 - oznacza to, że działalność z ust. 11 nie jest wykonywaniem czynności ubezpieczeniowych (w zakres których wchodzi oczywiście zawieranie umów ubezpieczenia), ergo nie jest działalnością ubezpieczeniową, niemniej zakład ubezpieczeń może ją wykonywać. W tym miejscu należy także zwrócić uwagę na wyrok TSUE z dnia 31 maja 2018 roku, wydany w sprawie C-542/16 - Länsförsäkringar Sak Försäkringsaktiebolag przeciwko Dödsboet efter Ingvar Mattsson oraz Jan-Erik Strobel i in., Lisa Bergström i in., Ann-Christin Jönsson i in., Daniel Röme i in., przeciwko Länsförsäkringar Sak Försäkringsaktiebolag ${ }^{13}$. W orzeczeniu tym - dotyczącym co prawda nieobowiązujących już aktów prawa unijnego, niemniej wciąż aktualnym - TSUE przyjałł, że doradztwo finansowe dotyczące inwestowania kapitału udzielone w ramach pośrednictwa ubezpieczeniowego dotyczącego zawarcia umowy ubezpieczenia na życie z ubezpieczeniowym funduszem kapitałowym wchodzi w zakres stosowania dyrektywy 2002/92 ${ }^{14}$, a nie w zakres stosowania dyrektywy 2004/39/ WE Parlamentu Europejskiego i Rady z dnia 21 kwietnia 2004 roku w sprawie rynków instrumentów finansowych zmieniającej dyrektywę Rady 85/611/EWG i 93/6/EWG i dyrektywę 2000/12/ WE Parlamentu Europejskiego i Rady oraz uchylającej dyrektywę Rady 93/22/EWG ${ }^{15}$. Chodziło

13. Zob. http://curia.europa.eu/juris/liste.jsf?language=pl\&td=ALL\&num=C-542/16 [dostęp: 2.11.2019].

14. Dyrektywa 2002/92/WE Parlamentu Europejskiego i Rady z dnia 9 grudnia 2002 r. w sprawie pośrednictwa ubezpieczeniowego (Dz. U. UE L 9 z dnia 15 stycznia 2003 r., s. 3-10).

15. Dz. U. UE 145 z dnia 30 kwietnia 2004 r., s. 1-44. 
więc de facto o rozstrzygnięcie, w oparciu o jakie przepisy działa pośrednik ubezpieczeniowy oferujący umowę ubezpieczenia z elementem inwestycyjnym (UFK). Dyrektywa 2002/92 nie zawierała żadnej definicji pojęcia „umowy ubezpieczenia” ani nie odsyłała w sposób wyraźny do prawa państw członkowskich w tym zakresie. Podobnie, tak jak to wynika zarówno z wymogów dotyczących jednolitego stosowania prawa Unii, jak i z zasady równości, zakresu terminu „umowa ubezpieczenia" należy poszukiwać z uwzględnieniem kontekstu, w który wpisuje się ta dyrektywa, i powinien on znaleźć w całej Unii Europejskiej autonomiczną i jednolitą wykładnię. Zdaniem Trybunału w zakres pojęcia „umowy ubezpieczenia”, o którym mowa w art. 2 pkt 3 dyrektywy 2002/92, umowa ubezpieczenia na życie z UFK, powinna regulować zapłatę składki przez ubezpieczonego oraz, w zamian za tę zapłatę, świadczenie usługi przez ubezpieczyciela (w przypadku śmierci ubezpieczonego lub wystapienia innego zdarzenia przewidzianego $w$ tej umowie). A ten element występuje przecież w każdej umowie ubezpieczenia z UFK. Z kolei dyrektywa 2014/6516, która nie obowiązywała w czasie postępowania w sprawie C-542/16, zmieniła dyrektywę 2002/92 poprzez dodanie nowego rozdziału III A, zatytułowanego „Dodatkowe wymogi w zakresie ochrony klientów dotyczące produktów inwestycyjnych opartych na ubezpieczeniu". Produkty te zostały zdefiniowane w art. 2 dyrektywy 2002/92 (pkt 13) jako produkty ubezpieczeniowe zapewniające wartość w dniu zapadalności lub wartość wykupu, w przypadku gdy ta wartość w dniu zapadalności lub wartość wykupu jest całkowicie lub częściowo narażona - bezpośrednio lub pośrednio na wahania rynków. Otóż z definicji tej wynika, że produkt inwestycyjny oparty na ubezpieczeniu zawiera element inwestycyjny, którego zmiana zależy od rozwoju rynku finansowego. Dyrektywa 2014/65/UE nie wprowadziła jednak zmian w definicji pośrednictwa ubezpieczeniowego znajdujacej się w art. 2 pkt 3 akapit pierwszy dyrektywy 2002/92, co oznacza, że doradztwo dotyczące takiego elementu inwestycyjnego stanowiło zdefiniowaną w tym przepisie działalność pośrednictwa ubezpieczeniowego. Ponadto fakt, iż rzeczony rozdział III A zawiera „dodatkowe” wymogi co do produktów inwestycyjnych opartych na ubezpieczeniu, wskazuje, że pośrednictwo takich produktów wchodziło już w zakres stosowania dyrektywy 2002/92 przed jej zmiana przez dyrektywę 2014/65/UE. Z powyższych rozważań TSUE wynika, że doradztwo finansowe dotyczące inwestowania kapitału udzielone w ramach pośrednictwa ubezpieczeniowego dotyczącego zawarcia umowy ubezpieczenia na życie z ubezpieczeniowym funduszem kapitałowym wchodziło w zakres stosowania dyrektywy 2002/92. TSUE nie miał więc wątpliwości, że „sprzedaż” umów z UFK jest pośrednictwem ubezpieczeniowym, ergoże umowy te nie stanowią odrębnej od umowy ubezpieczenia kategorii kontraktów. Element inwestycyjny jest tu bowiem tylko elementem dodatkowym.

Idąc dalej, nie sposób analizować zagadnienie istoty roszczenia o wypłatę wartości wykupu w oderwaniu od przepisów ustawy z dnia 15 grudnia 2017 roku o dystrybucji ubezpieczeń ${ }^{17}$, stanowiącej implementację Dyrektywy Parlamentu Europejskiego i Rady [UE] 2016/97 z dnia 20 stycznia 2016 roku w sprawie dystrybucji ubezpieczeń ${ }^{18}$. Sama dyrektywa już w punkcie 10 stanowi wprost, że dystrybucja umów ubezpieczeniowych, w tym ubezpieczeniowych produktów inwestycyjnych, powinna być regulowana niniejszą dyrektywą oraz dostosowana do dyrektywy 2014/65/UE, zaś

16. Dyrektywa Parlamentu Europejskiego i Rady 2014/65/UE z dnia 15 maja 2014 r. w sprawie rynków instrumentów finansowych oraz zmieniająca dyrektywę 2002/92/WE i dyrektywę 2011/61/UE (Dz. U. UE L 173, z dnia 12 czerwca 2014 r., s. 349-496).

17. Tekst jedn. Dz. U. 2018, poz. 2210.

18. Dz. U. UE L 26 z dnia 2 lutego 2016 r., s. 19-59. 
w punkcie 56, że w celu zapewnienia spójnej ochrony inwestorów i uniknięcia ryzyka arbitrażu regulacyjnego ubezpieczeniowe produkty inwestycyjne powinny podlegać nie tylko standardom prowadzenia działalności określonym dla wszystkich produktów ubezpieczeniowych, ale również szczególnym standardom mającym na celu uwzględnienie wbudowanego w te produkty elementu inwestycyjnego. Co się więc tyczy przepisów ustawy o dystrybucji ubezpieczeń, ustawodawca konsekwentnie posługuje się tu pojęciem „umowy ubezpieczenia na życie, o której mowa w grupie 3 działu I załącznika do ustawy o działalności ubezpieczeniowej i reasekuracyjnej”, ustanawiając jednocześnie dodatkowe wymogi dla takich umów lub podmiotów je oferujących (np. obowiązki informacyjne dotyczące wskaźnika kosztów dystrybucji czy obowiązki odnośnie do stosowania rozwiązań organizacyjnych służących zapobieganiu konfliktom interesów, tak aby nie miały one negatywnego wpływu na interesy klientów). Sama zaś definicja dystrybucji ubezpieczeń odnosi się wprost do umowy ubezpieczenia, zaś art. 4 ust. ? wskazanej ustawy expressis verbis wskazuje, że dystrybucję ubezpieczeń w zakresie grupy 3 działu I załacznika do ustawy o działalności ubezpieczeniowej i reasekuracyjnej może wykonywać wyłącznie agent ubezpieczeniowy, broker ubezpieczeniowy lub zakład ubezpieczeń. Po raz kolejny ustawodawca podkreśla więc, że w przypadku umów z UFK mamy do czynienia z ubezpieczeniem, które może być oferowane tylko przez zakłady ubezpieczeń oraz profesjonalnych pośredników ubezpieczeniowych.

Nie można też traktować - jak się wydaje - treści art. 23 ust. 1 pkt 2 u.dz.u.r. ${ }^{19}$ jako podstawy rozdzielenia „świadczeń z umowy ubezpieczenia” od „wypłaty wartości wykupu”. Przede wszystkim wskazany przepis określa obligatoryjne elementy umowy ubezpieczenia z UFK, co niejako per se oznacza, że mamy do czynienia ze świadczeniem, dla którego podstawą jest umowa ubezpieczenia. Nie można również zapomnieć o brzmieniu art. 805 § 2 pkt 2 k.c., zgodnie z którym świadczenie ubezpieczyciela polega w szczególności na zapłacie - przy ubezpieczeniu osobowym - umówionej sumy pieniężnej, renty lub innego świadczenia w razie zajścia przewidzianego w umowie wypadku w życiu osoby ubezpieczonej. Maciej Balcerowski oraz Ada Chudzik trafnie zwracają uwagę, że „Przepis ten niejako dwukrotnie wskazuje, iż katalog świadczeń w ramach umowy ubezpieczenia na życie nie ma charakteru zamkniętego, a więc może być ustalany przez strony. W takim znaczeniu dokonanie wykupu mogłoby być uznane za «inne» świadczenie ubezpieczyciela"20. Ponadto nie przekonuje argument, zgodnie z którym wypłata wartości wykupu nie jest świadczeniem ubezpieczeniowym, o którym mowa w art. 805 § 1 k.c., gdyż obowiązek jej dokonania nie powstaje w razie zajścia określonego w umowie wypadku ubezpieczeniowego, lecz w razie ziszczenia się innych zdarzeń, a w szczególności wypowiedzenia umowy albo jej rozwiązania wskutek nieopłacenia składki - chodzi więc o brak elementu losowości. Trzeba pamiętać, że wypłacane na rzecz ubezpieczającego czy ubezpieczonego świadczenia, których źródłem jest umowa ubezpieczenia, nie muszą w każdym przypadku być warunkowane wystapieniem wypadku ubezpieczeniowego ${ }^{21}$. Tak będzie chociażby w sytuacji żądania przez ubezpieczającego zwrotu składki za okres niewykorzystanej ochrony ubezpieczeniowej Nie ulega wạtpliwości, że źródłem

19. Zgodnie z tym przepisem w umowie ubezpieczenia na życie, jeżeli jest związana z UFK, zakład ubezpieczeń określa zasady ustalania wartości świadczeń z umowy ubezpieczenia z tytułu śmierci ubezpieczonego i dożycia ubezpieczonego do końca okresu ochrony ubezpieczeniowej, a także zasady ustalania wartości całkowitego i częściowego wykupu ubezpieczenia.

20. Zob. M. Balcerowski, A. Chudzik, Mieszany charakter ubezpieczeń na życie z UFK - krytyczna analiza, (http:// adcasum.pl/przedawnienie-roszczen-z-ufk/ [dostęp: 31.10.2019]).

21. Co z kolei oznacza, że do tego rodzaju roszczeń nie trzeba stosować chociażby art. 817 k.c. 
tych roszczeń jest zawarta umowa ubezpieczenia, co determinuje stosowanie trzyletniego terminu przedawnienia roszczeń. Analogiczny wniosek nasuwa się także przy tzw. regresie nietypowym (kiedy ubezpieczyciel żąda zwrotu odszkodowania wypłaconego poszkodowanemu, będącemu osobą trzecia] - jak trafnie wskazuje Marcin Krajewski, jeżeli regres oparty jest o postanowienia umowy ubezpieczenia, roszczenie z tego tytułu przedawniać będzie się w terminie przewidzianym w art. $819 \S 1$ k.c. ${ }^{22}$ Godzi się także podkreślić, że przepis ten ma charakter ogólny i znajduje zastosowanie do wszelkich roszczeń z umowy ubezpieczenia, niezależnie od tego czy dłużnikiem jest zakład ubezpieczeń czy ubezpieczajacy (ubezpieczony).

Ostatecznie należy zgodzić się z Michałem Romanowskim, który analizując kwestie świadczenia wykupu jako świadczenia głównego, trafnie podnosi, że „Funkcja ubezpieczeniowa oraz funkcja inwestycyjna umowy z UFK są ze sobą wzajemnie sprzężone i nierozerwalnie powiązane. Nie jest możliwe oddzielenie skutków prawnych funkcji ubezpieczeniowej od skutków prawnych funkcji inwestycyjnej. W przeciwnym razie istniałyby dwie odrębne umowy kreujace odrębne stosunki zobowiązaniowe. Umowa z UFK jest umową, w ramach której ubezpieczyciel i ubezpieczajacy występują równocześnie w roli dłużnika i wierzyciela. Świadczenie ubezpieczającego wynikające ze stosunku zobowiązaniowego wykreowanego umową z UFK sprowadza się do obowiązku zapłaty określonych w umowie składek i opłat. Świadczenie ubezpieczyciela polega zaś na zapewnieniu ochrony ubezpieczeniowej oraz zarządzaniu powierzonymi środkami, a w konsekwencji - na zapłacie oznaczonych sum pieniężnych (bezpośrednio lub pośrednio)"23. Za kluczowe należy uznać stwierdzenie: „Skoro funkcja ubezpieczeniowa oraz funkcja inwestycyjna umowy z UFK tworzą jeden integralny stosunek zobowiązaniowy, to do umowy z UFK przepisy art. 805 i nast. k.c. znajdują zastosowanie wprost, a nie per analogiam. Wartość składki przeznaczanej na funkcję ubezpieczeniową w umowie z UFK nie ma znaczenia dla jej kwalifikacji jako umowy, która podlega przepisom właściwym dla umów ubezpieczenia (art. 805 k.c. i nast.)”24. To z kolei oznacza, że: - do przedawnienia roszczeń stosujemy w omawianym przypadku właśnie art. 819 § 1 k.c.; oraz

- niecelowe jest odwoływanie się przez SN do dyspozycji art. 731 k.c., który dotyczy wszak umowy rachunku bankowego, a nie umowy ubezpieczenia (zresztą skoro w glosowanej uchwale zauważa się, że w przypadku umów z UFK nie dochodzi do absorbcji umowy ubezpieczenia w ramy prawne umów inwestycyjnych, to oznacza ni mniej, ni więcej, że do umów tych stosujemy art. 805-834 k.c.).

Względem powyższych wywodów poczynić trzeba jednak jedno istotne zastrzeżenie. Otóż rozróżnić należy sytuację, w której do wypłaty wartości wykupu dochodzi w oparciu o wiążące postanowienia umowy ubezpieczenia, od żądania zwrotu jego równowartości (w całości lub w części], ale na skutek stwierdzenia abuzywności klauzuli umowy odnoszącej się do tego świadczenia

22. Zob. M. Krajewski, Umowa ubezpieczenia. Art. 805-834 k.c. Komentarz, CH Beck, Warszawa 2016, s. 371. Należy także wskazać, że przepis art. 819 k.c. całkowicie abstrahuje od jakichkolwiek elementów losowości.

23. M. Romanowski, Czy świadczenie wykupu w umowach z UFKjest świadczeniem głównym?, „Wiadomości Ubezpieczeniowe" 2016, nr 2, s. 62. Nie można również zapomnieć o definicji ubezpieczeniowego funduszu kapitałowego [art. 3 ust. 1 pkt 50 u.dz.u.r.], zgodnie z którą w ubezpieczeniu, o którym mowa w dziale I w grupie 3 załącznika do tej ustawy, jest to wydzielony fundusz aktywów stanowiący rezerwę tworzoną ze składek ubezpieczeniowych, inwestowany w sposób określony w umowie ubezpieczenia. Z samej definicji wynika więc wskazywane przez M. Romanowskiego sprzężenie funkcji ubezpieczeniowej i inwestycyjnej (na poziomie składki, a więc świadczenia głównego ubezpieczającego) oraz określenie elementów inwestycyjnych w umowie ubezpieczenia.

24. Ibidem, s. 63. 
(np. określającej tzw. opłatę likwidacyjną) ${ }^{25}$. Jak już wspomniano, w uzasadnieniu wyroku z dnia 28 marca 2018 roku (V CSK 398/17) SN zwrócił uwagę, że stwierdzenie abuzywności postanowień umowy ubezpieczenia należy kwalifikować jako zdarzenie prawne rodzące obowiązek dokonania pomiędzy jej stronami odpowiednich rozliczeń, których podstawą są przepisy ustawy o nienależnym świadczeniu ${ }^{26}$ - należności będące przedmiotem zwrotu nie będą miały cech „świadczenia wykupu z umowy ubezpieczenia", a odwoływanie się do tego pojęcia umownego może mieć tylko charakter pomocniczy (np. rachunkowy). Stanowisko to, odnoszące się de facto do skutków stwierdzenia niedozwolonego charakteru postanowienia umownego, jest jak najbardziej prawidłowe, lecz determinuje dualistyczne podejście właśnie do kwestii terminu przedawnienia obu opisanych roszczeń. W drugim z opisanych przypadków materialnoprawną podstawą roszczenia o zapłatę będzie art. 410 § 2 k.c., ergo termin przedawnienia tego roszczenia będzie liczony zgodnie z art. 120 § 1 zd. 2 k.c. (jest to zobowiązanie bezterminowe), a jego okres będzie wynikał z art. 118 k.c. (wyniesie więc de lege lata i co do zasady 6 lat). Jak trafnie ujał to SN w wyroku z dnia 24 kwietnia 2013 roku ${ }^{27}$, jakkolwiek roszczenie o zwrot nienależnego świadczenia w warunkach conditio sine causa lub condictio causa finita powstaje zawsze na tle stosunku umownego i jest z nim nieodzownie funkcjonalnie związane, nie jest jednak roszczeniem wynikającym z umowy, źródłem jego powstania nie jest bowiem wola stron, ale przepis umowny, regulujący obowiązki występujące na skutek upadku umowy. Nie obejmuje go zatem termin przedawnienia stosowany do roszczeń z umowy ubezpieczenia.

\section{Konkluzje}

Z powyższych względów przyjąc należy, że mimo tego, iż umowa ubezpieczenia z UFK jest de facto i de iure umową o charakterze mieszanym, to zastosowanie do niej znajdą wprost przepisy k.c. o umowie ubezpieczenia, w tym także art. 819 § 1. Należy zgodzić się z SN, że w przypadku analizowanych umów nie dochodzi do wspomnianej absorbcji elementów ubezpieczeniowych

25. Właśnie takiej sytuacji dotyczyło pytanie prawne, na skutek którego wydano z kolei glosowane orzeczenie. Trzeba również pamiętać, że nie jest do końca jasny charakter świadczenia wykupu jako świadczenia z umowy ubezpieczenia. W postanowieniu z dnia 3 grudnia 2015 r. III CZP 87/15 (Legalis nr 1385122) SN odmówił podjęcia uchwały w sprawie pytania prawnego jednego z sądów powszechnych o treści „Czy świadczenie wypłacane przez ubezpieczyciela w przypadku przedterminowego rozwiązania umowy ubezpieczenia na życie wraz z UFK jest świadczeniem głównym czy ubocznym?”. SN przyjął, że w obrocie prawnym występuje obecnie wiele wariantów umowy ubezpieczenia z UFK i nie ma możliwości ustalenia sztywnych i uniwersalnych reguł odnośnie do kwalifikacji prawnej konkretnych postanowień tych umów. W omawianym zakresie wypowiedzi doktryny pozostają zróżnicowane - część autorów twierdzi, iż świadczenie wykupu jest świadczeniem głównym z umowy ubezpieczenia z UFK w rozumieniu art. $385^{1}$ k.c., jako swoista emanacja celu i funkcji tej umowy (zob. m.in. M. Szczepańska, Glosa do postanowienia SN z dnia 3 grudnia 2015 r., III CZP 87/15, „Prawo Asekuracyjne” 2016, nr 3, s. 98-103, M. Romanowski, op. cit., s. 57 i nast. czy M.P. Ziemiak, Postanowienia niedozwolone na tle umów ubezpieczenia. Studium cywilnoprawne, TNOiK, Toruń 2017, s. 359), inni zaś w ogóle nie uznają wykupu za świadczenie w rozumieniu art. 353 k.c. (zob. W. Kamieński, Główne świadczenia stron umowy ubezpieczenia na życie z ubezpieczeniowym funduszem kapitałowym, „Rozprawy Ubezpieczeniowe" 2014, nr 2, s. 56).

26. Precyzując - odpowiedzialność zakładu ubezpieczeń lokuje się w płaszczyźnie przepisów o bezpodstawnym wzbogaceniu i nienależnym świadczeniu (zob. wyrok Sądu Apelacyjnego w Łodzi z dnia 30 kwietnia 2014 r., I ACa 1209/13, Legalis nr 1067292].

27. IV CSK 596/12 (Legalis Numer 741811). 
przez inwestycyjne. Jednakże - wbrew stanowisku SN - regulacje zawarte zarówno w u.d.u., jak i w u.dz.u.r. nie pozostawiają wạtpliwości, że do umów ubezpieczenia z UFK stosujemy przepisy o umowie ubezpieczenia, gdyż mają one rezydualne znaczenie dla analizowanych kontraktów. To z kolei determinuje ustalanie terminu przedawnienia w oparciu właśnie o art. 819 § 1 k.c. Sytuacja ta wygląda jednak inaczej, kiedy mamy do czynienia z klauzulą abuzywną - w takim przypadku, wobec konieczności stosowania art. 410 k.c., przedawnienie wyniesie 6 lat (art. 118 k.c.).

\section{Wykaz źródeł}

Balcerowski M., Chudzik A., Mieszany charakter ubezpieczeń na życie z UFK - krytyczna analiza (http://adcasum.pl/przedawnienie-roszczen-z-ufk/ [dostęp: 31.10.2019]).

Kamieński W., Główne świadczenia stron umowy ubezpieczenia na życie z ubezpieczeniowym funduszem kapitałowym, „Rozprawy Ubezpieczeniowe” 2014, nr 2.

Krajewski M., Umowa ubezpieczenia. Art. 805-834 k.c. Komentarz, CH Beck, Warszawa 2016.

Romanowski M., Czy świadczenie wykupu w umowach z UFK jest świadczeniem głównym?, „Wiadomości Ubezpieczeniowe” 2016, nr 2.

Szczepańska M., Glosa do postanowienia SN z dnia 3 grudnia 2015 r., III CZP 87/15, „Prawo Asekuracyjne" 2016, nr 3.

Szczepańska M., Wypłata wartości wykupu w umowie ubezpieczenia na życie z UFK, „Wiadomości Ubezpieczeniowe" 2015, nr 3.

Ziemiak M.P., Postanowienia niedozwolone na tle umów ubezpieczenia. Studium cywilnoprawne, TNOiK, Toruń 2017.

\section{Gloss to resolution of the Supreme Court of August 10, 2018 [III CZP 13/18]}

The resolution concerns still controversial issue of life insurance contracts with an insurance capital fund. Specifically the Supreme Court stated that it is necessary to refer to article 118 of Polish Civil Code (PCC) to established statutory period of limitation of claims of so called policy surrender value. The Author challenges said conclusion and indicates that instead of article 118, article $819 \S 1$ of PCC ought to be invoked since an insurance contract is a basis for policy surrender value claims.

Key words: insurance capital fund, limitation of claims, policy surrender value, insurance contract.

DR MICHAL P. ZIEMIAK - adiunkt w Katedrze Prawa Ubezpieczeniowego i Medycznego UMK w Toruniu, radca prawny.

mpz@umk.pl

https://orcid.org/0000-0001-8543-9458 
